\title{
DEVELOPMENT SUPPORTING EMPLOYEE BEHAVIOURS
}

\author{
Barbara Józefowicz ${ }^{a}$ \\ ${ }^{a}$ Department of General Management, Faculty of Economic Sciences and \\ Management, Nicolaus Copernicus University, Toruń, Poland, e-mail: \\ barbara.jozefowicz@umk.pl
}

\begin{abstract}
The article presents the results of the research conducted on Positive Organizational Potential and its role as a key factor of companies' development. The data analyzed in this article come from two stages of the research. In the first part an experts session was conducted to determine the force of the impact of each of 35 selected Development Supporting Employee Behaviours on companies' development. In the second stage of the research (done by postal survey) 104 leading Polish companies were examined. Respondents in this stage were top-managers, who have rated the intensity of particular employee behaviours identified in their companies and described their company's performance. This methodology allowed us to compare the identified behaviours with the indicators of development. This research was the first of this type that was carried out in the world, where the specific behaviour influencing development was identified. It is only a starting point for further research, which is to be conducted in the area of management of described relations in business practice.
\end{abstract}

Keywords: Positive Management, Employee Behaviours, Company's Development

Paper type: Research paper

A company's success is dependent in extreme part on the people who work there. The effects of business, in fact, are effects of employees who being under the influence of various factors, first of all still remain just people. They are people with a set of individual attributes of personality, value systems, needs and emotions. From the perspective of managers it seems very interesting how to create and control consciously these behaviours which impact the company positively.

This article concentrates on the positive employee behaviour which appears in companies and determines their development. The present article shows the results of the research conducted on Positive Organizational Potential and its role as a key factor of companies' development by the Chair of General Problems of Management at the Faculty of Economic Sciences and Management, Nicolaus Copernicus University.

At the outset the research team selected 35 employee behaviours which can contribute to organization's development based on Positive Organizational Scholarship (Cameron, Dutton, Quinn, 2003). According to this conception, when

JOURNAL

OF POSITIVE

MANAGEMENT

Vol. 1, No. 1, 2010, pp. 75-84 (C) Copyright by Wydawnictwo Naukowe Uniwersytetu Mikołaja Kopernika 
DEVELOPMENT SUPPORTING

Barbara Józefowicz people experience positive emotions in their workplace they are more motivated to achieve excellence and above-average results. The greater commitment to work leads to achieving quicker the company's goals and gives better individual satisfaction. Furthermore, these behaviours in their positive expression radiate to the whole environment and are a kind of driving force that encourages continuous improvement.

After the experts session was conducted to determine the force of the impact (on a scale from 0 to 10) of particular behaviours on the company's development, some areas were identified where the behaviours were manifested and these included among other things: productivity, innovation, product and process quality, satisfaction of stakeholders, reputation, competitive position, profitability, and - especially in a globalizing world - an effective internationalization. Based on the knowledge and experiences of the experts participating in the research, the hierarchy of Development Supporting Employee Behaviours was developed and it is shown in Table 1.

\begin{tabular}{|c|c|}
\hline Development Supporting Employee Behaviours & $\begin{array}{l}\text { The average } \\
\text { force of } \\
\text { impact on } \\
\text { company's } \\
\text { develop- } \\
\text { ment }\end{array}$ \\
\hline Employees treat customers' comments as a valuable way to improve their work & 7.9 \\
\hline Employees consider in their activity customers' satisfaction & 7.6 \\
\hline Employees solve problems creatively & 7.6 \\
\hline When competing with others, employees follow the rules of 'fair play' & 7.6 \\
\hline Employees express freely their opinions & 7.2 \\
\hline $\begin{array}{l}\text { Employees willingly commit themselves in activities undertaken by their organiza- } \\
\text { tion }\end{array}$ & 7.1 \\
\hline Employees do their best at work & 7.1 \\
\hline Employees commit themselves fully in the realization of their superiors' decisions & 6.9 \\
\hline $\begin{array}{l}\text { When employees face difficulties they do not become discouraged but they seek } \\
\text { ways to overcome them }\end{array}$ & 6.9 \\
\hline Employees provide support and information to their colleagues when they need it & 6.9 \\
\hline Employees show interest in their company's situation & 6.7 \\
\hline $\begin{array}{l}\text { Employees treat critical comments and different opinions expressed by others as a } \\
\text { chance for a discussion and improving their performance }\end{array}$ & 6.7 \\
\hline Employees talk proudly of their company & 6.7 \\
\hline Employees are not afraid of experimenting in their activity & 6.7 \\
\hline Employees admit to making mistakes & 6.6 \\
\hline Employees individually attempt to solve problems relating to their work & 6.5 \\
\hline Employees listen to each other's opinions & 6.5 \\
\hline
\end{tabular}

Table1.

The impact of Development Supporting Employee Behaviours on the company's development 


\begin{tabular}{ll}
\hline Employees know their strengths and undertake activity in which they can use them & 6.4 \\
\hline $\begin{array}{l}\text { Employees deepen their knowledge not only about what is directly connected with } \\
\text { their positions, but also master other skills (e.g., social skills) }\end{array}$ & 6.1 \\
\hline $\begin{array}{l}\text { Employees agree to taking over of team leadership by those who possess adequate } \\
\text { competences at a given level }\end{array}$ & 6.1 \\
\hline Employees talk openly with one another & 5.9 \\
\hline $\begin{array}{l}\text { Employees ask questions and ask their colleagues for help when they do not know } \\
\text { something or cannot do something }\end{array}$ & 5.9 \\
\hline Employees do not generate unnecessary costs & 5.7 \\
\hline Employees do not leave their work incomplete & 5.6 \\
\hline When employees formulate their objective they focus on benefits not on difficulties & 5.5 \\
\hline $\begin{array}{l}\text { Employees analyze information obtained in the dimension of its usefulness for the } \\
\text { organization }\end{array}$ & 5.4 \\
\hline $\begin{array}{l}\text { Employees commit themselves in various activities supporting their company's } \\
\text { social responsibility }\end{array}$ & 5.3 \\
\hline Employees declare their need to undergo certain training & 5.2 \\
\hline $\begin{array}{l}\text { Employees balance their careers and private life (they do not neglect their personal } \\
\text { life) }\end{array}$ & 5.2 \\
\hline $\begin{array}{l}\text { Employees do not 'rest on their laurels'; having achieved an objective, they think } \\
\text { about another and more challenging one }\end{array}$ & 5.0 \\
\hline Employees do not look for another job & 5.0 \\
\hline $\begin{array}{l}\text { Employees inform other work mates about possibilities for their development (e.g., } \\
\text { training, publications, etc.) }\end{array}$ & 4.6 \\
\hline Employees reveal their dreams and passions & 4.6 \\
\hline Employees are kind to one another & 4.5 \\
\hline Employees perceive success as a stage on their way to achieving perfection \\
\hline
\end{tabular}

DEVELOPMENT SUPPORTING

Barbara Józefowicz their positions, but also master other skills (e.g., social skills)

competences at a given level

The average assessment of the impact strength of these supporting employee behaviours on business development is valued by experts between 4.1 - the weakest impact, and 7.9 - the strongest influence. The most important behaviour influencing companies' development has proved treating customers' comments by employees as a valuable way to improve their work. Such feedback is very important, especially from the quality point of view understood in the broad sense, particularly, those aspects that are critically dependent on the human factor. This is not about the implementation of a centrally planned program of activities throughout the enterprise to adapt to the needs of customers, but an autonomous process of improving their individual work following the indications signalled by clients. It is closely connected to the second factor (the average force of the impact on the enterprise's development - 7.6), namely, employees consider customers' satisfaction in their activity. It is obvious that the service that completely satisfies the customer brings new clients to the company, increases loyalty and gives additional benefits in terms of higher reputation. Certainly, this is not possible

Table 1. Continued 
DEVELOPMENT SUPPORTING

Barbara Józefowicz to be obtained through formal procedures, but only through a genuinely sincere expression of willingness to meet employee expectations. Only then is it credible for the receiver and effective in the long term.

The same assessment of the impact on companies' development (7.6) received two other behaviours. The first is that employees solve encountered problems creatively, which provides innovative, efficient and smooth functioning of the organization. This is extremely important in many different situations and should not be restricted only to the so-called moments of crisis but should also be revealed in everyday work, when employees can easily fall into an ordinary routine and neglect the potential points of development. Creative behaviours of employees constitute definitely a desirable factor for development. Just as the other equivalent behaviour, involving competition in accordance with the "fair play' principles. The rivalry between workers is beneficial to the company, if victory is not a goal to be achieved at any price.

In the third position, in the terms of assessment value, with the average force of impact on the company's development of 7.2 was expressing opinions freely. The lack of fear of a negative reaction from superiors or from other workers and the freedom to express their own opinions turned out to be, according to experts' evaluation, a significant factor influencing development. This undoubtedly stimulates creativity as well as emotional commitment of the employee in the work, by intense involvement in activities undertaken by their organization which was considered to be almost equally important (7.1). Both due to this factor (7.1), and to the full commitment in the realization of their superiors' decisions (6.9) employees can do their best at work. Here we should pay attention to the fact that companies' development also depends on employees' providing support and information to their colleagues when they need them. Furthermore, when employees face difficulties they do not become discouraged but they seek ways of overcoming them.

Next items assessed (with the value of 6.7 points) are the behaviours demonstrating identification with the company. This is showing interest in the company's situation by employees and their talking proudly of the company. Experts gave the same value of the strength of influence on the organization's development to the situations when employees treat critical comments and different opinions expressed by others as a chance for a discussion and improving their performance and also when they are not afraid of experimenting in their activity. It means that much importance should be attached to openness to criticism and its constructive usage. The following items in this hierarchy are directly related to them: admitting to mistakes made by employees (6.6), listening to each other's opinions (6.5), attempting to solve problems connected with their work individually (6.5), that means showing self-reliance and resourcefulness at work. 
The behaviour - employees know their strengths and undertake activity in which they can use them (the average force of impact on company's development 6.4) has a slightly weaker influence on company's development. The next one in the ranking with the result of 6.1 was employees deepen their knowledge not only about what is directly connected with their positions, but also master other skills for example social skills). According to the experts' opinions, the same value is ascribed to the behaviour - employees agree to the taking over of team leadership by those who possess adequate competences at a given level (6.1). And finally with the assessment of 5.9 was placed the frankness in conversations between employees as well as asking questions and asking their colleagues for help when they do not know something or cannot do something.

Unnecessary costs generating behaviours was ranked relatively low (average force of influence 5.7) as well as employees do not leave their work incomplete (5.6). Maybe this relatively low value forces impact the company's development in way due to a greater tendency toward creativity and innovation rather than cost-effectiveness.

Increasingly lesser impact on the company's development of the organization have the following behaviours: when employees formulate their objective they focus on benefits not on difficulties (value 5.5), employees analyze information obtained in the dimension of its usefulness for the organization (5.4), employees commit themselves in various activities supporting their company's social responsibility (5.3), employees declare their need to undergo certain training (5.2), employees balance their careers and private life (5.2), employees do not 'rest on their laurels'; having achieved an objective, they think about another and more challenging one (5.0) and they do not look for another job (5.0).

The last four behaviours listed in Table 1 are characterized by less than fiftypercent influence on business development which may mean that they are not particularly desirable manifestations. These include the mutual informing other employees about possibilities for their development such as training, publications, etc. (4.6), reveal their dreams and passions (4.6), being kind to one another (4.5). The least important from the viewpoint of development was the behaviour - employees perceive a success as a stage on their way to achieving perfection (4.1). This may mean that, regardless of whether employees perceive the further perspective, it is not significant for the company's development, if they focus on the efficient completion of the current task. Moreover, such reasoning is consistent with the common belief that strategic thinking is the domain of chief executives.

In conclusion of this stage of the experts research it is worth mentioning that, generally, it was declared that company's development is determined by all the 35 Development Supporting Employee Behaviours (on average of 48.6\%, while in $51.4 \%$ by other factors). But the values given by experts individually fluctuate between $40 \%$ and $90 \%$.
DEVELOPMENT SUPPORTING

Barbara Józefowicz 
DEVELOPMENT SUPPORTING

Barbara Józefowicz

Table 2.

The intensity of behaviours manifesting fundamental values of employees from the surveyed companies
The next stage of the research was included the determination of the intensity of previously identified Development Supporting Employee Behaviours in business organizations. Within the postal survey there were examined 104 leading Polish companies. At this stage the respondents were top-managers, as they constitute the group that has the knowledge of almost all activities conducted in their companies and the effects of these activities. They have rated the intensity of particular Development Supporting Employee Behaviours in their institutions on a scale ranging from $0 \%$ to $100 \%$. The results obtained in this way can be divided according to the values underlying the Positive Organizational Culture, and they rely upon the assumptions of a Positive Organizational Scholarship.

The first category of behaviours refers to the fundamental values recognized by the surveyed companies as one of the key points including honesty, respect for truth, and justice. This is primarily about such behaviours that result from peoples' willingness to follow goodness, though sometimes differently understood. Personal interests interlace with organizational ones, and even with those of the whole society. The list of such behaviours categorised by the intensity of their occurrence and observed in the surveyed enterprises is presented in Table 2.

\begin{tabular}{lc}
\hline \multicolumn{1}{c}{ Development Supporting Employee Behaviours } & $\begin{array}{c}\text { Average } \\
\text { intensity } \\
(\%)\end{array}$ \\
\hline $\begin{array}{l}\text { Employees balance their careers and private life (they do not neglect their } \\
\text { personal life) }\end{array}$ & 68.8 \\
\hline Employees consider in their activity customers' satisfaction & 67.5 \\
\hline $\begin{array}{l}\text { When employees formulate their objective they focus on benefits not on } \\
\text { difficulties }\end{array}$ & 59.8 \\
\hline Employees talk openly with one another & 58.8 \\
\hline $\begin{array}{l}\text { Employees commit themselves in various activities supporting their com- } \\
\text { pany's social responsibility }\end{array}$ & 53.9 \\
\hline Employees do not generate unnecessary costs & 53.5 \\
\hline Employees are not afraid of experimenting in their activity & 51.6 \\
\hline Employees admit to making mistakes & 51.4 \\
\hline
\end{tabular}

The average assessments of the behaviours grouped under this category range between $68.8 \%$ and $51.4 \%$. This level can be interpreted only as an average, which is definitely not a reason for pride. The most popular behaviour here turned out to be balancing career and private life. That means that employees pursuit happiness through professional work without neglecting personal life, reconciling career with family duties. The harmonious combination of these two areas of everyone's life is a guarantee of psychological balance needed to perform the job well. It is very important in any work that requires independent thinking. However, the

\begin{abstract}
is very inportant in any work that requires independent thinking. However, the
\end{abstract}


intensity of $68.8 \%$, although the highest in this group, does not give evidence of that is the standard.

A similar conclusion applies to the behaviour - employees consider in their activity customers' satisfaction. Because this behaviour was evaluated by experts as one of the strongest that influence the company's development, its occurrence in practice is insufficient.

Unfortunately, behaviours that require from employees maintaining personal courage do not occur frequently in the surveyed organizations. These include frankness in conversations between employees (58.8\%), the lack of fear of experimenting in their activity (51.6\%), and admitting mistakes (51.4\%). Such consciously daring attitude arise from the atmosphere in the organization and are formed by Positive Potential of Organization (Stankiewicz, 2010). Without the courage to experiment in the work it is difficult to imagine the innovation or creativity. However, this courage needs to be respected by managers, and, what is more, they should even encourage it.

Behaviours that express action undertaken to reach perfection together with the above-average results make up the second category. It was decided to qualify here mainly those behaviours that relate to self-improvement and development of individual competence taken with a view to increasing the efficiency of the work. The outcome of the research performed in this area is presented in Table 3.

\begin{tabular}{lc}
\hline \multicolumn{1}{c}{ Development Supporting Employee Behaviours } & $\begin{array}{c}\text { Average } \\
\text { intensity } \\
(\%)\end{array}$ \\
\hline $\begin{array}{l}\text { Employees do their best at work } \\
\text { Employees treat customers' comments as a valuable way to improve their } \\
\text { work }\end{array}$ & 67.7 \\
\hline $\begin{array}{l}\text { Employees deepen their knowledge not only about what is directly } \\
\text { connected with their positions, but also master other skills (e.g., social } \\
\text { skills) }\end{array}$ & 60.5 \\
\hline $\begin{array}{l}\text { Employees do not leave their work incomplete } \\
\text { Employees do not 'rest on their laurels'; having achieved an objective, } \\
\text { they think about another and more challenging one }\end{array}$ & 60.1 \\
\hline $\begin{array}{l}\text { Employees perceive a success as a stage on their way to achieving } \\
\text { perfection }\end{array}$ & 58.2 \\
\hline $\begin{array}{l}\text { Employees treat critical comments and different opinions expressed by } \\
\text { others as a chance for a discussion and improving their performance }\end{array}$ & 52.4 \\
\hline
\end{tabular}

Among the behaviours that fall into this category the highest intensity has the behaviour - employees do their best at work. It is precisely this behaviour that increases the level of quality of the business processes implemented in the
DEVELOPMENT SUPPORTING

Barbara Józefowicz 
DEVELOPMENT SUPPORTING

Barbara Józefowicz

Table 4.

The intensity

of behaviours

manifesting activity and creativity among the employees of the surveyed companies surveyed enterprises, labour productivity growth, and innovation (Pearson's rank correlation coefficients are respectively $0.46,0.36$ and 0.32 ). However, the average intensity of 67.7 is not a satisfactory result. It means that almost $33 \%$ of employees work on average at most, and they do not make full use of their abilities. In extreme cases, this percentage goes up to $90 \%$. This is a very unfavourable situation, especially if its focus is long-term. Since it can and even should be tolerated as a short-term one, i.e., the so-called transition periods, resulting from a momentary drop in motivation, or personal incapacity, which is exposed to each man by virtue of its nature. However, the persistent attitude of employees is totally unacceptable.

Behaviours in this group are linked to a sense of responsibility and commitment to the work. However, their intensity was rated by respondents lower than the occurrence of the separate values that have been identified over the seventy percent level. The employees' self-improvement area also leaves a lot to be desired. But without the individual development of people working for an organization is difficult to achieve company's development.

Another group of behaviours which seem to favour particularly the business development are those demonstrating activity and creativity. Table 4 presents the scores granted for intensity.

\begin{tabular}{lc}
\hline \multicolumn{1}{c}{ Development Supporting Employee Behaviours } & $\begin{array}{c}\text { Average } \\
\text { intensity } \\
(\%)\end{array}$ \\
\hline Employees declare their need to undergo certain training & 64.9 \\
\hline $\begin{array}{l}\text { Employees commit themselves fully in the realization of their superiors' } \\
\text { decisions }\end{array}$ & 63.2 \\
\hline $\begin{array}{l}\text { Employees willingly commit themselves in activities undertaken by their } \\
\text { organization }\end{array}$ & 61.9 \\
\hline Employees individually attempt to solve problems relating to their work & 61.5 \\
\hline Employees solve problems creatively & 60.9 \\
\hline $\begin{array}{l}\text { Employees know their strengths and undertake activity in which they can } \\
\text { use them }\end{array}$ & 60.5 \\
\hline $\begin{array}{l}\text { When employees face difficulties they do not become discouraged but they } \\
\text { seek ways to overcome them }\end{array}$ & 59.2 \\
\hline $\begin{array}{l}\text { Employees analyze information obtained in the dimension of its usefulness } \\
\text { for the organization }\end{array}$ & 56.3 \\
\hline
\end{tabular}

As we can see in Table 4 activity and creativity range from about $56.3 \%$ to $64.9 \%$. And once again, these are not impressive results. Taking initiative individually is not a standard in the surveyed organizations. Even declaring own training needs does not apply to $35 \%$ of employees, and other activities are even weaker. This means that in Polish companies full commitment in the company's affairs 
is infrequent similar to the attitude towards using people's own knowledge and abilities. It is worth remembering that improvement of employees' commitment is closely associated with higher levels of consumer satisfaction, additional profits and ultimately better financial results.

The final complement of the Positive Organizational Scholarship is a principle of building positive relationships with colleagues and with the organization. Therefore, these two areas can be analyzed separately and the first one is presented in Table 5.

It can be noticed that the average intensities of this group are slightly higher than in the previous tables. Positive relationships at work are in fact in the interests of employees due to the necessity of daily contacts and their connection with the quality of life. A friendly atmosphere and helpful attitude of employees contribute to greater job satisfaction (Robbins, 2003) and more satisfactory personal life.

\begin{tabular}{lc}
\hline \multicolumn{1}{c}{ Development Supporting Employee Behaviours } & $\begin{array}{c}\text { Average } \\
\text { intensity } \\
(\%)\end{array}$ \\
\hline $\begin{array}{l}\text { Employees are kind to one another } \\
71.0\end{array}$ & 70.5 \\
\hline $\begin{array}{l}\text { Employees ask questions and ask their colleagues for help when they do not } \\
\text { know something or cannot do something }\end{array}$ & 68.5 \\
\hline $\begin{array}{l}\text { Employees provide support and information to their colleagues when they } \\
\text { need it }\end{array}$ & 65.7 \\
\hline $\begin{array}{l}\text { Employees agree to the taking over of team leadership by those who possess } \\
\text { adequate competences at a given level }\end{array}$ & 64.5 \\
\hline $\begin{array}{l}\text { Employees listen to each other's opinions } \\
\text { Employees freely express their opinions }\end{array}$ & 56.3 \\
\hline When competing with others, employees follow the rules of 'fair play' & 55.9 \\
\hline $\begin{array}{l}\text { Employees inform other work mates about possibilities for their development } \\
\text { (e.g., training, publications, etc.) }\end{array}$ & 53.4 \\
\hline Employees reveal their dreams and passions & \\
\hline
\end{tabular}

Positive relationships between employees impact positively the effectiveness of the team. Approximately $70 \%$ of the intensity of kindness and attitude toward mutual assistance is quite a lot, but does not indicate the prevalence of what would be desirable. Especially if we bear in mind the fact that the survey results indicate a significant impact of these aspects, in particular, on improving the quality, innovation and financial results.

Some of the behaviours relating to the conduct of relations with the entire organization are included in Table 6.

This is by far the strongest group of Development Supporting Employee Behaviours occurring in the surveyed companies. Over $70 \%$ intensity of the sense
DEVELOPMENT SUPPORTING

Barbara Józefowicz

. 
DEVELOPMENT SUPPORTING

Barbara Józefowicz

Table 6.

The intensity of behaviours manifesting employees' identification with the surveyed companies of identification of employees with the organization sounds optimistic. This has a huge impact on the credibility of the company's service and the eventual perception of the company in customer's eyes since the company's reputation is built not only by marketing campaigns but rather by how employees are treated as well as how they treat customers. Furthermore, the research indicated that showing pride in relation to the company affects particularly the increase in customer satisfaction (Pearson's rank correlation coefficients 0.41), interest in corporate affairs and not looking for another job increases the quality of business processes (Pearson's rank correlation coefficients are respectively 0.45 and 0.41 ).

\begin{tabular}{lc}
\hline Development Supporting Employee Behaviours & $\begin{array}{c}\text { Average } \\
\text { intensity } \\
(\%)\end{array}$ \\
\hline Employees show interest in their company's situation & 76.3 \\
\hline Employees talk proudly of their company & 72.1 \\
\hline Employees do not look for another job & 70.3 \\
\hline
\end{tabular}

The above analysis of the impact Development Supporting Employee Behaviours on the company's development is the first one of this type in the world. It is only a starting point for further research concerning particularly the occurrence of relations described in business practice.

\section{References}

Cameron, K. S., Dutton, J. E., Quinn, R. E., (2003) Positive Organizational Scholarship: Foundations of a New Discipline, Berrett-Koehler Publishers, San Francisco.

Robbins, S.P. (2003) Essentials of Organizational Behavior, $7^{\text {th }}$ edition, Prentice Hall, New Jersey.

Stankiewicz, M.J. (2010) Pozytywny Potencjat Organizacji. Wstęp do użytecznej teorii zarządzania, TNOiK Dom Organizatora, Toruń. 